\title{
PSYCHE
}

\begin{tabular}{lll}
\hline VOL. XIX. FEBRUARY, 1912. No. 1 \\
\hline
\end{tabular}

\section{NEW NORTH AMERICAN DIPTERA.}

\author{
By Charles W. Johnson, \\ Boston Society of Natural History, Boston, Mass.
}

In the genus Cylindrotoma there is considerable variation in the venation of both species and individuals. The three specimens of $C$. distinctissima Wiedemann received from Herr. M. P. Riedel show very little variation, the second posterior cell is of almost uniform length (Fig. 1). The figure shown by Prof. J. G. Needham of " $C$. distinctissima Meigen, after van der Wulp" (N. Y. State Museum, bull. 124, pl. 15, fig. 4, 1908) does not represent the species. In $C$. americana $\mathrm{O}$. S. the two specimens before me from Capens, Moosehead Lake, Maine, July 11, 1907, have the second posterior cell the same length as the third (Fig. 2). Regarding the venation of $C$. splendens Doane (Fig. 5 after Doane) he says:- "Submarginal cell either longer or shorter than the first posterior cell. In two of my specimens it is longer in one wing and shorter in the other." In C. juncta Coq. the base of the second posterior cell is slightly before the base of the third. C. tarsalis sp. nov. (Fig. 4) has normally a venation similar to C. distinctissima, but there are many abnormalities. Among the fourteen specimens, four have the second posterior cell as long as the third in one or both wings; one has the vein $\mathbf{M}^{1}$ obsolete with only a slight indication of the vein at the margin; another specimen has a very abnormal venation, in one wing a small cell is present at the base of the submarginal and first posterior cells, extending from the marginal cell to and partly over the base of the discal cell; the junction of vein $\mathrm{M}^{1}$ is imperfect in both wings. In $C$. anomala sp. n. (Fig. 3) the first posterior cell is petiolate and the anterior cross-vein extends to the petiole. 

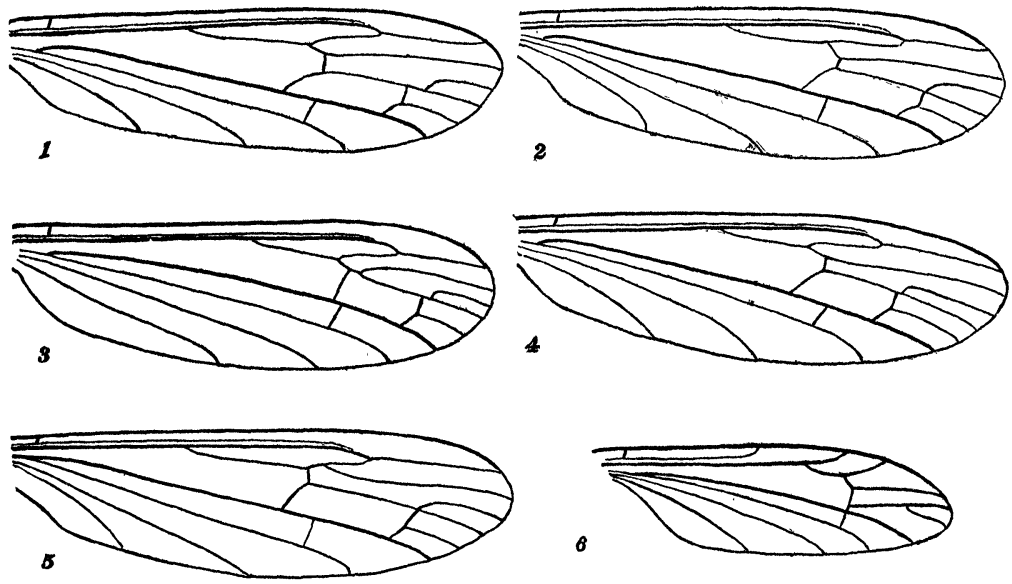

\section{Cylindrotoma tarsalis sp. nov. (Figure 4.)}

Male. Front and occiput black, with a slight grayish pollen; rostrum and palpi yellow, tips brown, the three basal joints of the antennæ entirely light yellow, flagellum brown, densely pubescent, the joints slender and not contracted at the ends. Thorax light yellow, with three narrowly separated opaque black stripes, the dorsal one extending from the collar to the transverse suture, the lateral stripes begin at the middle of the dorsal stripes, curving inward beyond the suture, and extending nearly to scutellum; pleuræ light yellow; a brown spot above the front coxæ, another between the front and middle coxæ, and also at the base of the halteres; scutellum and metanotum yellow, the latter bearing two faint brown spots. Abdomen brown, a wide dorsal line, venter and genitalia yellowish. Coxæ yellow, femora, tibiæ and metatarsi dark brown, the remainder of the tarsi (except the extreme tip) yellowish white. Halteres infuscated above, yellowish below. Wings grayish hyaline, covered with minute hairs, stigma obsolete, veins brown and hairy. Length $8 \mathrm{~mm}$.

Fourteen specimens, Woodworth's Lake, Bleecker, N. Y., August 19, 1909. Holotype and six paratypes in the author's collection. The remaining paratypes returned to the collector, Charles $\mathbf{P}$. Alexander.

\section{Cylindrotoma (?) anomala sp. nov. (Figure 3.)}

Male. Very similar to $C$. tarsalis in general appearance. The palpi are longer and the antennæ much shorter; the joints of the flagellum are irregular in size and more abruptly tapering. The stripes on the thorax are the same, the collar is slightly infuscated; the brown spot above the front coxæ is present, but the other spots of the pleuræ and metanotum are wanting. The abdomen is similar in color but the genitalia are much larger and of an entirely different structure, with prominent forceps and appendages. The legs have the same peculiar coloring of the tarsi but the wings have quite a different venation as shown in the figure. Length, $8 \mathrm{~mm}$. 
One specimen, Woodworth Lake, Bleecker, N. Y., August 19, 1909, collected by Charles P. Alexander.

This species is placed here provisionally awaiting more material. It seems strange that two species taken at the same time and place should resemble each other so closely in color. The five posterior cells would indicate its place in this genus, but the antennæ and genitalia are quite different from the typical Cylindrotoma.

\section{Elliptera alexanderi sp. nov. (Figure 5.)}

Male. Rostrum and palpi black, antennæ light yellow, the second and third joints globose, flagellum slender, verticils long, tip of the flagellum brown. Thorax yellow with three broad, brown stripes, the middle one obscurely divided before the suture; scutellum and metanotum brown, margined with yellow; pleuræ yellow with three brown longitudinal stripes, the upper one somewhat obsolete, the lower one broader than the others and extending over the bases of the coxæ. Abdomen brown, posterior margins of the segments and venter yellowish, genitalia large, yellow; tips of the appendages black. Legs yellow; the entire front femora, apex of the middle femora and a subapical band on the posterior femora dark brown; tibiæ and bases of the metatarsi whitish, bases and apices of the front and middle tibiæ, tips of the posterior tibiæ and all of the tarsi including the outer half of the metatarsi dark brown. Halteres yellow the knobs slightly infuscated. Wings hyaline with a slight brownish tinge, stigma brown with a light spot on each side, the costa and costal and subcostal cells white. Length, $4.5 \mathrm{~mm}$. The female differs but little from the male. The front and middle metatarsi are entirely brown; the ovipositor entirely yellow.

Six specimens, Sport Island, Sacandaga River, N. Y., July 5, 1909, and August 24, 1910. Holotype and two paratypes in the author's collection; the others in the collection of the collector, Mr. Charles P. Alexander.

\section{Leptis gracilis sp. nov.}

Male. Front and occiput blackish, grayish pollinose, with two slight tubercles above the antennæ; ocelligerous tubercle black; eyes widely separated; palpi and antennæ yellow, aristæ black. Thorax yellow, with narrow somewhat obsolete stripes due largely to rows of fine black hairs; pleuræ and scutellum yellow. Abdomen slender, yellow, first segment with a black spot below the scutellum, the remaining segments with broad basal bands of black. Halteres and legs light yellow, a small black dot at the base of the femora on the inner side; tarsi somewhat brownish toward the tips. Wings hyaline, veins light brown, anal cell closed, with a short petiole extending to the margin. Length, $6 \mathrm{~mm}$.

The female differs but little from the male except that the black on the first segment of the abdomen extends entirely across the base. The front is slightly wider and has three slight grooves, the tubercles are obsolete.

Six specimens Holotype and Allotype.-Amsden, Vt., July 10, 1908 (C. W. Johnson). Paratypes.-Mt. Ascutney, Vt., above 2,000 ft., July 11, 1908 (C. W. Johnson.) Mt. Greylock, Mass., August 8, 1907 (Owen Bryant). Types in the New England collection of the Boston Society of Natural History. 
This interesting species is not a typical Leptis, for the eyes of the male are dichoptic. In form it resembles Dialysis, but the front tibiæ are without spurs and the hind tibiæ have two as in typical Leptis. The anal cell is closed, but the open anal cell is not a fixed character. Among twenty-six specimens of L. mystacea seven have the anal cell closed, as shown in Williston's Manual, 1908, p. 157, fig. 51 , although the table on page 163 says open. This character also varies in $L$. plumbea (4 open and 3 closed) and L. punctipennis ( 2 open and 8 closed), one specimen has it open on one wing and closed on the other. A specimen of L. albicornis has the discal cells open.

\section{Chrysopila davisi sp. nov.}

Female. Head velvety black; antennæ black. Thorax black, covered with a dense golden yellow tomentum, similar to C. thoracica pleuræ, scutellum and the entire abdomen velvety black. Femora black, tibiæ and metatarsi light yellow; the remainder of the tarsi blackish. Halteres black. Wings smoky black. Length, $15 \mathrm{~mm}$.

Two specimens collected by Mr. William T. Davis, Clayton, Georgia, "2,0003,700 ft." June, 1900. Holotype in the author's collection. This species seems to be intermediate between $C$. velutina, Lw. and $C$. thoracica Fabr., the wings and abdomen are like the former and the thorax like the latter.

\section{Nemotelus bonnarius sp. nov.}

Male. Face shining black, facial projection moderate, proboscis double the length of the head, bent slightly beyond the middle; a small spot above the base of the antennæ; eyes sub-contiguous; antennæ black; thorax and scutellum black, with a small white spot on the humeri. Abdomen mostly white, the first segment black except at the posterior angles; second white except for a short anterior, central margin of black; third white except a small black spot at the anterior angle; fourth black, except for a narrow lateral and posterior margin, which is often interrupted posteriorly leaving a dorsal spot, fifth black, with a narrow lateral and posterior margin dorsally expanded; venter black with a large irregular white spot on the second, often extending onto the third segment. Femora black, tips of the femora and the greater part of tibiæ and tarsi white, middle of the posterior tibiæ black and of the front and middle tibiæ brown. Halteres white. Wings hyaline, veins light yellow, third vein furcate. Length, $5 \mathrm{~mm}$.

Female. Front very broad with a small white spot at the lower end of the frontal orbits, narrowly separated from an elongated spot on the facial orbits; proboscis short and thick, bent near the middle. Abdomen black, with a small, white, dorsal spot on the posterior margins of the second, third, fourth and fifth segments, the lateral margins are narrowly margined with white, which often extends for some distance around the posterior angles.

Ten males and eight females, Farewell Creek, South Saskatchewan, August, 1907, collected by Mrs. Varah A. Armstrong. One male, Ramsey Co., Minn. Holotype and Allotype in the author's collection.

Allied to $N$. kansensis Adams, but distinguished by the greater amount of black 
on the abdomen of the male, which in $N$. kansensis is confined to the fifth segment. The female of the latter has a wider lateral margin and larger triangular spots on the abdomen.

\section{Euparyphus greylockensis sp. nov.}

Male. Face and inferior orbits black, a yellow, arrow-shaped mark on the side of the face, orbits with white pubescense; frontal triangle yellow, ocellar triangle and occiput black, ocelli yellow; antennæ black. Thorax black, sparsely covered with yellowish hairs; two spots, the humeri with stripes extending to the suture and the post-alar callosities, yellow; pleuræ black, with long white hairs, a large triangular spot just forward of the wing with a second spot between this and the middle coxa yellow. Scutellum yellow, the extreme base and tips of the spines black. Abdomen black and marked with yellow as follows: base of the first segment very narrowly margined; the third segment with oblique stripes, each scarcely one-third the width of the segment in length, extend from the posterior angles, between these and the middle of the segment are two small spots; fifth segment with a central marginal triangle; venter black, a spot on the lateral margin of the third, and the posterior margin of the fifth segment yellow. Femora black, tip of the femora, all of the tibiæ and the basal half of the tarsi yellow, the outer half of the tarsi and a band on the middle of the posterior tibiæ black. Halteres yellow. Wings hyaline, third longitudinal vein simple. Length, $6 \mathrm{~mm}$.

One specimen, Mt. Greylock, Mass., August 8, 1907 (Owen Bryant). Type in the Boston Society of Natural History. Distinguished from E. tetraspilus Loew, by its yellow scutellum and peculiar abdominal markings. $E$. bellus Loew, is separated from $E$. tetraspilus by third longitudinal being forked.

\section{NOTES ON PSYLLIDA: LIVIA. ${ }^{1}$}

\section{By Edith M. Рatch.}

As a preparation for work with New England Psyllids, it has been the good fortune of the writer to receive specimens from widely separated localities for systematic study. Much of this material has no data other than the locality and date of collection, and it is with the hope that host plant and other biological information may be added by collectors from time to time, that these meagre records are given as a beginning. Photographs of the wing, head and caudal segment are given for the most part instead of detailed description. In order to connect the published account with the specimens studied, the accession numbers of each specimen are given together with what data are available.

\footnotetext{
1 Papers from the Maine Agricultural Experiment Station: Entomology No. 51.
} 

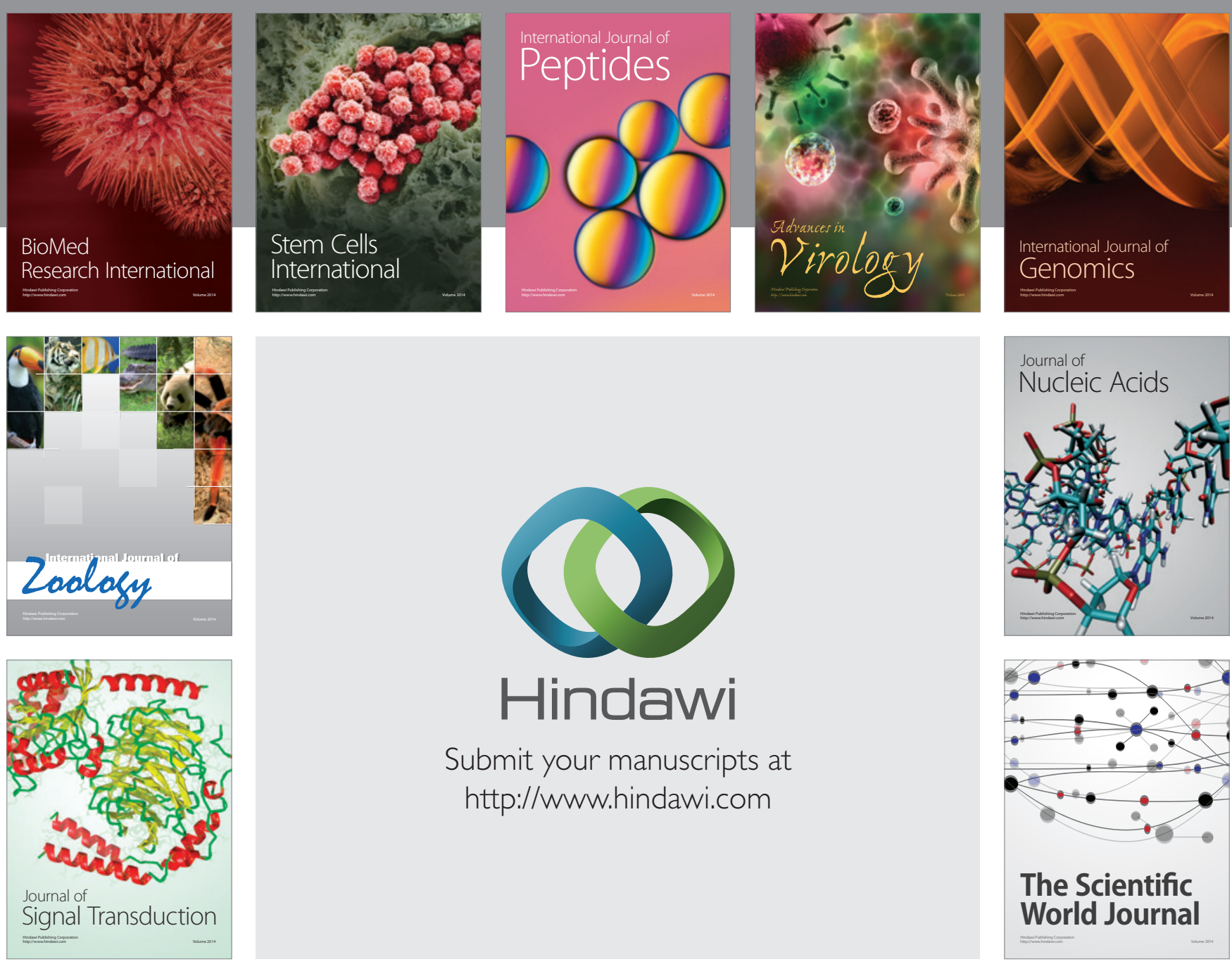

Submit your manuscripts at

http://www.hindawi.com
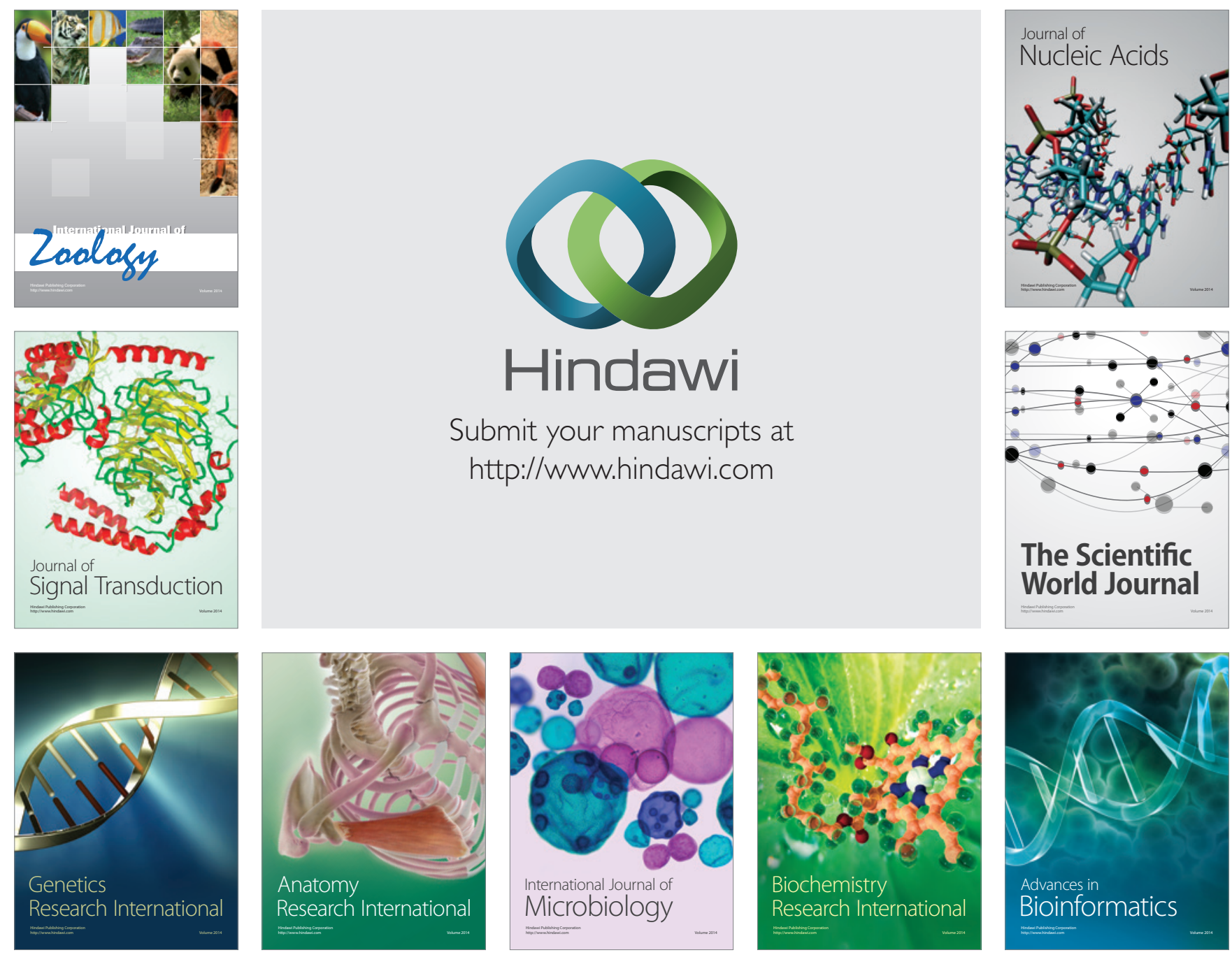

The Scientific World Journal
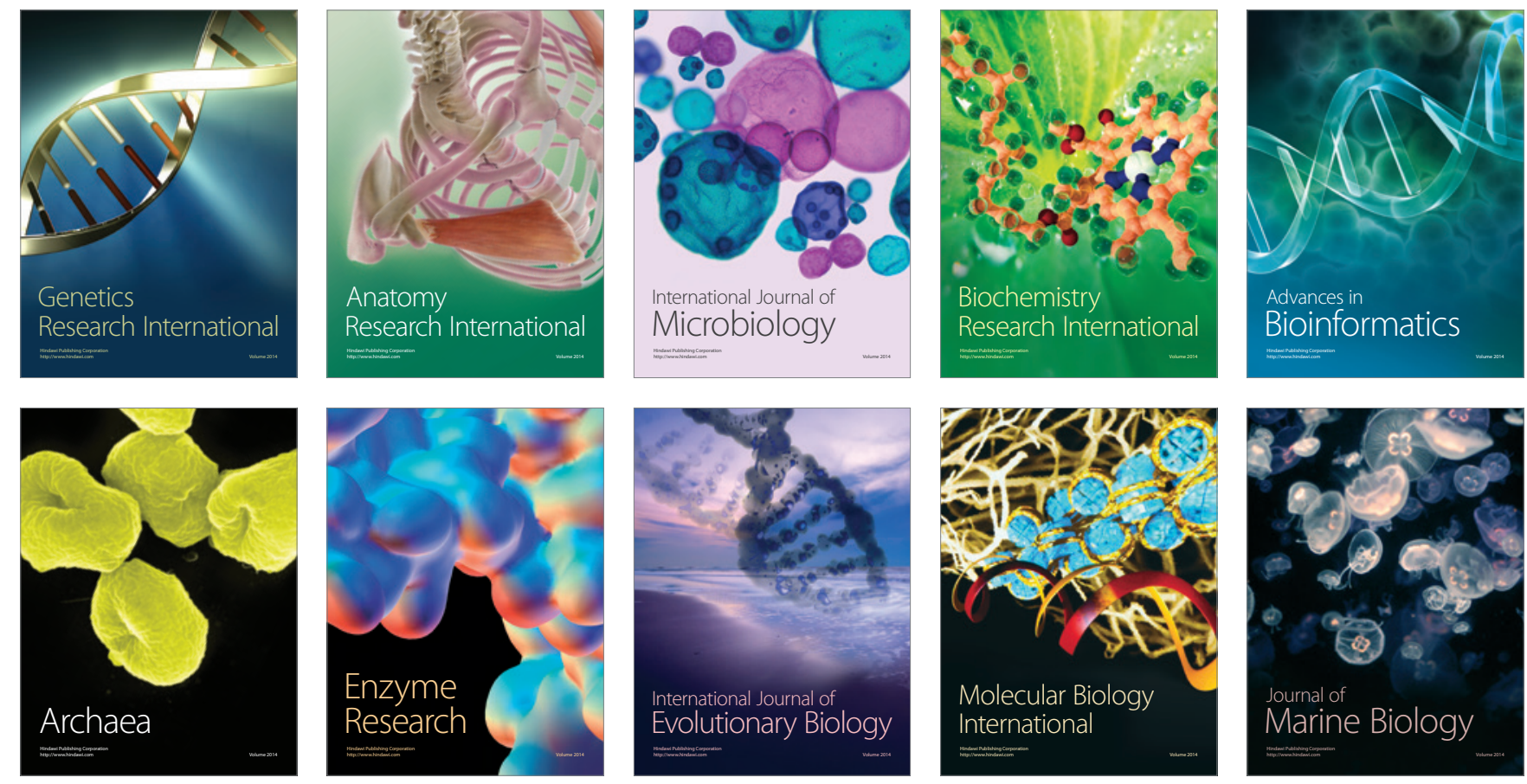